\title{
Evaluation of current therapeutic approach to obstructive and perforated colorectal cancers
}

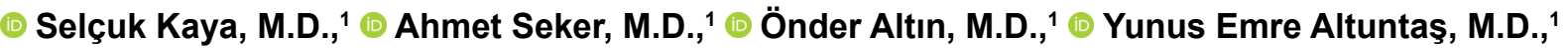

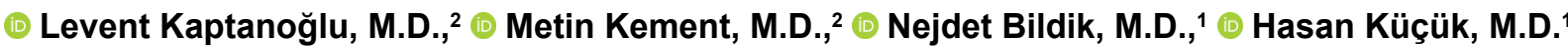

\begin{abstract}
1Department of General Surgery, University of Health Sciences, Kartal Dr. Lütfi Kırdar Training and Research Hospital, İstanbul-Turkey ${ }^{2}$ Department of General Surgery, Bahçeşehir Univercity Faculty of Medicine, VM Medical Park Hospital, İstanbul-Turkey
\end{abstract}

\begin{abstract}
BACKGROUND: Late diagnosis continues to be a significant problem in the treatment of colorectal cancer (CRC). Most cases require emergency surgical intervention due to acute intestinal obstruction or perforation. This retrospective study was formed from an assessment of the clinical presentation, treatment, early results, and survival of patients with CRC undergoing emergency surgery for acute obstruction or perforation.
\end{abstract}

METHODS: Between 2012 and 2017, 612 patients underwent surgery for CRC. In all, 179 patients who required emergency treatment were retrospectively evaluated according to age, gender, significant comorbidities, physiological status, surgical indications, tumor location, tumor stage, perioperative blood transfusion rate, type of surgery, and the length of the operation and hospitalization.

RESULTS: In total, I 52 (85\%) patients had a complete obstruction and 27 (I5\%) patients had a perforation. A major postoperative complication was identified nearly in half of the patients. The overall mortality rate was $12 \%$ (22 patients). Mortality was seen in $12 \%$ ( 18 patients) cases received surgery due to obstruction and in I5\% (four patients) cases received surgery due to perforation. Perioperative blood transfusion and a high Acute Physiology and Chronic Health Evaluation II score were independent factors that predicted a major complication. Advanced age and perioperative blood transfusion were statistically independent prognostic factors for mortality.

CONCLUSION: Consisted with the findings of studies in the literature, the results of this study also revealed a high perioperative morbidity and mortality rate in patients with CRC who required urgent surgery. Our findings suggest that early detection and treatment of CRC with screening programs can be life-saving.

Keywords: Colorectal cancer; obstruction; perforation.

\section{INTRODUCTION}

Colorectal cancers (CRC) are the second and third most common type of cancer among women and men in the world, respectively. ${ }^{[I]}$ CRC occurs in three different forms as hereditary, sporadic, or familial. Family history, with an altered gene leads to a specific type of tumor and a younger age initially constitutes hereditary form. The familial form is seen in family members with a genetic component and as well as environmental factors. This form does not have the same direct pattern of inheritance. Sporadic CRC may occur without a family history of the disease and is usually detected in the elderly population (60-80 years).

Neoplastic polyps, such as tubular and villous adenomas, are seen in $95 \%$ of CRC cases. $^{[2]}$

Despite advances in the diagnosis, treatment, and screening, CRC continues to be one of the leading causes of cancer deaths globally. ${ }^{[3]}$ Early elective surgical resection is the gold standard; however, many CRC cases require urgent surgeries due to acute intestinal obstruction, perforation, or both.

Cite this article as: Kaya S, Seker A, Altın Ö, Altuntaş YE, Kaptanoğlu L, Kement M, et al. Evaluation of current therapeutic approach to obstructive and perforated colorectal cancers. Ulus Travma Acil Cerrahi Derg 2019;25:589-596.

Address for correspondence: Selçuk Kaya, M.D.

Kartal Dr. Lütfi Kırdar Eğitim ve Araştırma Hastanesi, Genel Cerrahi Kliniği, İstanbul, Turkey

Tel: +90 216 - 4583000 E-mail: selcukkaya_36@hotmail.com

Ulus Travma Acil Cerrahi Derg 2019;25(6):589-596 DOI: 10.14744/tjtes.2019.03828 Submitted: 04.08.2018 Accepted: 04.02.2019 Online: 25.10.2019

Copyright 2019 Turkish Association of Trauma and Emergency Surgery 
There are some reports indicating that $6-30 \%$ of the patients with CRC show symptoms or have late complications. ${ }^{[4]}$ In addition to a lessening in 5-year survival, higher mortality and morbidity rates were seen in the patients with CRC, received urgent surgeries. ${ }^{[5]}$ Recently, it has been observed that the adverse effects of emergency surgery in patients with complicated colon cancer have limited perioperative turnover. The long-term survival of both emergency and elective surgery patients is similar. ${ }^{[6]}$ It has been reported that in some studies, survival differences between patients undergoing emergency and elective CRC surgery are decreasing. ${ }^{[7]}$ Meticulous dissection can provide considerable benefits, even in cases of urgent surgery and massive resection. The present study aims to evaluate the early results of treatment and surveillance analyzes in patients with obstruction or perforation due to colorectal cancer.

\section{MATERIALS AND METHODS}

\section{Study Design}

In this study, data from 612 patients who underwent surgical treatment for CRC between the years 2012-2017 were evaluated. One hundred seventy-nine patients (29.2\%) required urgent surgery and are included in our study. Data were analyzed according to age, gender, significant comorbidities, physiological status, surgical indications, localization and stage of the tumor, blood transfusion requirement during surgery, surgical technique and duration of surgery and hospital stay.

Indications for emergency surgery were peritonitis, which was diagnosed by history taking and physical examination, findings of abdominal or systemic sepsis and clinical findings of obstruction. Patients with intestinal obstruction who could not be rectified by conservative methods, findings of obstruction, or perforation on radiological examinations and operated within four days of symptom onset were considered urgent. Patients who had only adenocarcinoma were included in this study. Patients, having cancer through familial adenomatous polyposis and inflammatory bowel diseases or other than adenocarcinoma, and operated in another hospital, were excluded from this study. Patients without clinical findings of obstruction and perforation were also criteria for exclusion.

\section{Data Collection and Definitions}

This study was approved by our institutional Ethics committee. Patient files were reviewed for general and major morbidity and mortality as well as age, sex, major comorbidities, physiological status, surgical indications, location of the tumor, stage, transfusion requirement, type of surgery, duration of the operation and hospital stay.

At the time of the diagnosis, severe major organ dysfunction and chronic disease that required specific drug treatment were considered as co-morbidities. The American Society of
Anesthesiologists (ASA) classification ${ }^{[8]}$ and the Acute Physiology and Chronic Health Evaluation II (APACHE II) scoring system $^{[9]}$ were used preoperatively to investigate surgical and anesthesia risks and to group the patients according to the severity of the disease. The patients were divided into two categories: perforation and obstruction without perforation. The perforated patient group was divided into two groups according to the position of the perforated area: adjacent perforation of the tumor and at least $2 \mathrm{~cm}$ of remote perforation. The left branch of the middle colic artery was considered the border for proximal and distal tumors. The TNM Classification of Malignant Tumours (American Joint Committee on Cancer, $8^{\text {th }}$ edition) was used to evaluate the tumors. One hundred seventy-eight patients were staged by applying standard surgical techniques. Patients with no distant organ metastasis, no suspicion of residual disease after surgery, and patients with a clear surgical margin were considered cases of curative resection. Major complications were morbidities that disrupt respiratory, circulatory and excretory systems. Deaths within the first 30 days after surgery were accepted as surgical mortality. The posthospitalized data were obtained by calling the patients or polyclinic visit charts.

\section{Statistical Analysis}

Analyses were performed using IBM SPSS Statistics for Windows, Version 20.0 (IBM Corp., Armonk, NY, USA). Data with a normal distribution were analyzed using t-tests. Nonnormally distributed data were described using the median and interval and analyzed with the Mann-Whitney $U$ test. Relationships between the variables in the cross-tabulation were analyzed, if necessary, using a Chi-Square test or Fisher's exact test. Data normality was analyzed using the Kolmogorov-Smirnov test. Univariate and multivariate analyses were performed to determine major morbidity and mortality. $\mathrm{P}<0.05$ was considered significant. Kaplan-Meier survival curves were used to predict the overall survival (OS) and disease-free survival (DFS) of patients who underwent emergency CRC surgery.

\section{RESULTS}

In total, I 52 (85\%) patients had obstruction and 27 (I5\%) patients had a perforation. The location of the tumor was as follows: right colon in 34 patients, transverse colon in 30 patients, splenic flexure or descending colon in 29 patients, sigmoid colon in 70 patients, and rectum in 16 patients. Left colon cancer patients had more obstruction and perforation. Patients' demographic details and tumor characteristics were summarized in Table I.

The mean age of the study patients was 65.3 years (range: 3I-97 years). The comorbid disease was diagnosed in $70 \mathrm{pa}-$ tients (39\%). Common comorbid diseases were hypertension (38\%), diabetes mellitus (22\%), cardiovascular diseases (I5\%) and chronic obstructive pulmonary disease $(7 \%)$. Male pa- 
tients were predominant in obstruction cases, whereas female patients were predominant in perforation cases $(p=0.027)$. Advanced tumor stage (Stage III-IV) was seen in 107 of the patients (70\%) with an obstructing carcinoma, and in 18 $(67 \%)$ of the patients with a perforating tumor $(p=0.348)$.

In this study, 31 patients (I7\%) were classified as ASA class III, I I 3 patients (63\%) were ASA class III, and 35 patients (20\%) were ASA class IV. The APACHE II score median average was between three and 21 . The mean obstruction and perforation scores were 6.8 (SD 2.3) and 8.9 (SD 4.I), respectively $(p=0.000 \mathrm{I})$. In this study, 152 patients $(85 \%)$ for obstruction and 27 patients (15\%) for perforation were operated.

Curative surgery was applied to 95 cases (53\%). The rates of general and curative resection in the patients in the obstructed colon group were $82 \%$ and $53 \%$, respectively, while patients in the perforated colon group were $88 \%$ and $52 \%$, respectively. $89 \%$ of the perforated patients had stoma without resection. Some cases received primary anastomosis. Patients with perforation received end stoma. Resection and anastomosis were performed in the majority of the obstructed right colon patients (74\%). Bypass anastomosis was performed for one patient with advanced tumor disease. Colostomy was carried out in 18 of 128 patients with left colon carcinoma. The only stoma was created in six patients with a stage-bystage resection plan. Permanent stoma was created in 21 patients due to inoperable disease. One hundred ten patients $(86 \%)$ with left-sided tumors were resectable and resected. Preoperatively additional procedures were applied due to various reasons. Generally, local advanced disease state, incidental findings, additional biopsies and iatrogenic causes were the main reasons. Additional treatments were administered to 33 patients (18\%) for various reasons. An appendectomy

Table I. Demographics and tumor characteristics

\begin{tabular}{|c|c|c|c|}
\hline & $\begin{array}{c}\text { Obstruction } \\
\text { n (\%) }\end{array}$ & $\begin{array}{c}\text { Perforation } \\
\text { n (\%) }\end{array}$ & $\begin{array}{l}\text { Total } \\
\text { n (\%) }\end{array}$ \\
\hline Total patients & 152 & 27 & 179 \\
\hline Age & $65.1 \pm 13.2$ & $66.5 \pm 14.8$ & $65.3 \pm 13.4$ \\
\hline \multicolumn{4}{|l|}{ Sex } \\
\hline Female & $61(40.1)$ & $17(63.0)$ & $78(43.6)$ \\
\hline Male & 91 (59.9) & $10(37.0)$ & I0I (56.4) \\
\hline \multicolumn{4}{|l|}{ Tumor stage* } \\
\hline I-II & 44/I5I (28.9) & $9 / 27(33.3)$ & $53 / 178(29.6)$ \\
\hline III & $45 / 151(29.6)$ & $8 / 27(29.6)$ & $53 / 178(29.6)$ \\
\hline IV & 62/151 (40.8) & $10 / 27(37.0)$ & $72 / 178(40.2)$ \\
\hline \multicolumn{4}{|l|}{ Histologic grade* } \\
\hline Well differentiated & $17 / 131$ (1I.2) & $3 / 23(11.1)$ & $20 / 154$ (1I.2) \\
\hline Moderately differentiated & $86 / 131$ (56.6) & |4/23 (5I.9) & $100 / 154(55.9)$ \\
\hline Poorly differentiated & $28 / 131$ (18.4) & $6 / 23(22.2)$ & $34 / 154(19.0)$ \\
\hline \multicolumn{4}{|l|}{ Nodal status** } \\
\hline Negative (N0) & $49 / 131$ (37.4) & $12 / 23(52.2)$ & $61 / 154(39.6)$ \\
\hline Positive (NI) & $40 / 131(30.5)$ & $5 / 23(21.7)$ & $45 / 154(29.2)$ \\
\hline Positive (N2) & $42 / 131(32.1)$ & $6 / 23(26.1)$ & $48 / 154(31.2)$ \\
\hline \multicolumn{4}{|l|}{ TNM $^{* *}$} \\
\hline TI-T2 & $3 /|3|(2.0)$ & $0 / 23$ & $3 / 154$ (1.7) \\
\hline T3 & $99 / 131$ (65.1) & $15 / 23(55.6)$ & II4/I54 (63.7) \\
\hline $\mathrm{T} 4$ & $29 / 131(19.1)$ & $8 / 23(29.6)$ & $37 / 154(20.7)$ \\
\hline \multicolumn{4}{|c|}{ Extramural lymphovascular invasion ${ }^{* * * *}$} \\
\hline Present & $68 / 130(44.7)$ & I2/23 (44.4) & $80 / 153(44.7)$ \\
\hline Absent & $62 / 130(40.8)$ & II/23 (40.7) & $73 / 153(40.8)$ \\
\hline \multicolumn{4}{|l|}{ Extramural perineural invasion ${ }^{* * * *}$} \\
\hline Present & $71 / 130(46.7)$ & $17 / 23(63.0)$ & $88 / 153(49.2)$ \\
\hline Absent & $59 / 130(38.8)$ & $6 / 23(22.2)$ & $65 / 153(36.3)$ \\
\hline
\end{tabular}

*I missing data. ${ }^{* *} 25$ missing data. ${ }^{* * *} 26$ missing data. 
Table 2. Major complications after emergency surgery for colorectal cancer

\begin{tabular}{|c|c|c|c|c|c|}
\hline & & $\begin{array}{l}\text { Obstruction } \\
\text { (n) }\end{array}$ & $\begin{array}{c}\text { Perforation } \\
\text { (n) }\end{array}$ & $\begin{array}{l}\text { Total } \\
\text { n (\%) }\end{array}$ & $\mathbf{p}$ \\
\hline \multirow[t]{5}{*}{ Gastrointestinal } & Ostomy-related complication & 9 & 3 & $12(6.7)$ & 0.395 \\
\hline & Intraabdominal abscess/peritonitis & 10 & 18 & $28(15.6)$ & 0.000 \\
\hline & Prolonged ileus & 23 & 4 & $27(15.1)$ & 0.966 \\
\hline & Anastomotic leakage & 7 & - & $7(3.4)$ & - \\
\hline & Intra-abdominal hemorrhage & 2 & - & $2(1.1)$ & - \\
\hline \multirow[t]{3}{*}{ Respiratory } & Pneumonia & 4 & - & $4(2.2)$ & - \\
\hline & Respiratory failure & 20 & 4 & $24(13.4)$ & 0.764 \\
\hline & Pulmonary embolism & I & - & I (0.6) & - \\
\hline Renal & Acute renal failure & 9 & 5 & $14(7.8)$ & 0.041 \\
\hline \multirow[t]{2}{*}{ Cardiac } & Congestive heart failure & 3 & - & $3(1.7)$ & - \\
\hline & Myocardial infarction & 3 & - & $3(1.7)$ & - \\
\hline \multirow[t]{2}{*}{ Other } & Catheter-related sepsis & 1 & 1 & $2(1.1)$ & - \\
\hline & Deep venous thrombosis & 3 & - & $3(1.7)$ & - \\
\hline
\end{tabular}

was necessary for II patients, a cholecystectomy in seven, a hernia repair in five, a splenectomy in three, a small bowel resection in four, and a hepatic biopsy in three patients. Mortality was present in four patients $(\% / 2)$ who were administered an additional procedure. Two patients had an appendectomy, one case had cholecystectomy and another patient had a small bowel resection. There was no finding indicating that additional procedures may cause mortality. Besides, there was no difference between mortality rates in patients with or without additional procedures. The mean duration of operation was 137 minutes (49-285 minutes). Fifty-five patients (31\%) received a perioperative blood transfusion.

Postoperative major complications occurred in 87 patients (48\%) (Table 2). In patients with obstruction and perforation, the major complication rate was similar, with $48 \%$ in both cases. Digestive and respiratory system problems were common complications. $39 \%$ of the patients developed complications, such as surgical site infection, urinary infection and dehiscence, in the incision. A relaparotomy was required for 18 (10\%) patients. The complication of colostomy was seen in six patients, anastomotic leak in five patients, abdominal abscess in four patients, evisceration in two patients and hemorrhage in one patient in these patients. Eighteen patients operated for obstruction and four operated for perforation died; mortality rates were $12 \%$ and $15 \%$, respectively. The cause of death was sepsis in 12 patients, multi-organ failure in six patients, respiratory failure in three cases, and a pulmonary embolism in one case. All of the post-surgical deaths for a perforation were due to sepsis. The most frequent cause of death in patients treated for obstruction was a multi-organ failure. Among patients who underwent curative surgery, colostomy was seen with fewer complications than the primary anastomosis, with complication rates of $38 \%$ and $61 \%$, respectively. Patients averaged 21.4 days in the hospital (SD 10.8 days). Obstructive patients were not statistically significant, with 23.5 days (SD 10.9 days) and 19.1 days (SD 9.2 days), respectively, with more stay at the hospital than with perforation. No statistically significant difference was found between the patients who underwent postresection anastomosis and those who had a stoma.

Univariate analyses showed that sex, age, tumor location, distant perforation from the tumor, ASA class, APACHE II score and major complications of blood transfusion did not significantly affect the risk (Table 3). Concerning mortality (Table 4), only age was a prognostic variable in univariate analysis. In multivariate analysis, perioperative blood transfusion and high APACHE II class were shown to be independent indicators of a major complication. Advanced age and perioperative blood transfusion in multivariate analysis were independent prognostic factors for mortality (Table 5).

Kaplan-Meier survival curves were used to predict the overall survival (OS) and disease-free survival (DFS) of patients who underwent emergency CRC surgery. Figure I displays the survival curves stratified by obstruction and perforation. As shown in Figures $l a$ and $b$, the OS and DFS were not significantly different in patients who underwent emergency surgery. Figures Ic and $d$ illustrate the lack of a significant difference between the OS and DFS of patients who had an emergency operation due to obstruction and the patients who had a perforation $(p=0.059$ and $p=0.303$, respectively; log-rank test).

\section{DISCUSSION}

Emergency surgery for CRC is associated with a poor outcome. $^{[5]}$ The majority of patients who have emergency CRC surgery are operated for perforation or an obstruction. Ac- 
Table 3. Univariate analysis of clinical factors in relation to major complication

\begin{tabular}{|c|c|c|}
\hline Categories & $\begin{array}{c}\text { Major complication } \\
\text { n (\%) }\end{array}$ & $\mathbf{p}$ \\
\hline \multicolumn{3}{|l|}{ Age } \\
\hline$\leq 65$ & $38 / 86(44.2)$ & 0.256 \\
\hline$>65$ & $49 / 93(52.7)$ & \\
\hline \multicolumn{3}{|l|}{ Sex } \\
\hline Female & $33 / 78(42.3)$ & 0.139 \\
\hline Male & $54 / 101$ (53.5) & \\
\hline \multicolumn{3}{|l|}{ Tumor location } \\
\hline Right & 20/5I (39.2) & 0.113 \\
\hline Left & $67 / 128(52.3)$ & \\
\hline \multicolumn{3}{|l|}{ Tumor stage* } \\
\hline I-II & $28 / 53(52.8)$ & 0.435 \\
\hline III & $26 / 53(49.1)$ & \\
\hline IV & $32 / 72(44.4)$ & \\
\hline \multicolumn{3}{|l|}{ Indication for surgery } \\
\hline Obstruction & $74 / 152(48.7)$ & 0.406 \\
\hline Cancer site perforation & $5 / 14(35.7)$ & \\
\hline Proximal site perforation & $8 / 13(6 \mid .5)$ & \\
\hline \multicolumn{3}{|l|}{ ASA class } \\
\hline I-II & $|2 / 3|(38.7)$ & 0.461 \\
\hline III & $58 / 113(51.3)$ & \\
\hline IV & 17/35 (48.6) & \\
\hline \multicolumn{3}{|l|}{ APACHE II score } \\
\hline$<8$ & $31 / 127(24.4)$ & 0.461 \\
\hline$\geq 8$ & $24 / 52(46.1)$ & \\
\hline \multicolumn{3}{|l|}{ Perioperative blood transfusion } \\
\hline Yes & $31 / 55(56.4)$ & 0.167 \\
\hline No & $56 / 124(45.2)$ & \\
\hline
\end{tabular}

*I missing data.

cording to the literature, between $7 \%$ and $40 \%$ of CRC cases require emergency surgery. ${ }^{[10]}$ Similar results were found in our study. We also observed that it was older patients who more often required emergency surgery due to CRC. ${ }^{\left[{ }^{[1]}\right]}$ The CRC tumors were most commonly located in the rectosigmoid region. ${ }^{[2]}$ As has been reported in the literature, the majority of our patients have had left colon and rectal tumors.

Obstructive CRC tends to progress locally. ${ }^{[13]}$ In patients with perforation, tumor staging is also seen to be more advanced than in non-emergency patients. ${ }^{[12]}$ In our study, there was no statistically significant difference between obstructive and perforated tumors.

Patients undergoing emergency surgery due to right colon cancer are more likely to have locally advanced disease and
Table 4. Univariate analysis of clinical factors in relation to major mortality

\begin{tabular}{lcc}
\hline Categories & $\begin{array}{c}\text { Mortality } \\
n(\%)\end{array}$ & p \\
\hline
\end{tabular}

\begin{tabular}{|c|c|c|}
\hline \multicolumn{3}{|l|}{ Age } \\
\hline$\leq 65$ & $3 / 86(3.5)$ & \\
\hline$>65$ & $19 / 93(20.4)$ & 0.000 \\
\hline \multicolumn{3}{|l|}{ Sex } \\
\hline Female & II/78 (14.1) & \\
\hline Male & $11 / 101$ (10.9) & 0.516 \\
\hline \multicolumn{3}{|l|}{ Tumor location } \\
\hline Right & $4 / 51(7.8)$ & \\
\hline Left & $18 / 128(14.1)$ & 0.319 \\
\hline \multicolumn{3}{|l|}{ Tumor stage* } \\
\hline I-II & $4 / 53(7.5)$ & 0.282 \\
\hline III & $5 / 53(9.4)$ & \\
\hline IV & $13 / 72(18.1)$ & \\
\hline \multicolumn{3}{|l|}{ Indication for surgery } \\
\hline Obstruction & 18/I52 (II.8) & \\
\hline Cancer site perforation & $\mathrm{I} / \mathrm{I} 4(7.1)$ & \\
\hline Proximal site perforation & $3 / 13(23.1)$ & 0.412 \\
\hline \multicolumn{3}{|l|}{ ASA class } \\
\hline I-II & $2 / 31(6.5)$ & \\
\hline III & $12 / 113(10.6)$ & \\
\hline IV & $8 / 35(22.9)$ & 0.086 \\
\hline \multicolumn{3}{|l|}{ APACHE II score } \\
\hline$<8$ & $6 / 127(4.7)$ & \\
\hline$\geq 8$ & $22 / 52(42.3)$ & 0.072 \\
\hline \multicolumn{3}{|l|}{ Perioperative blood transfusion } \\
\hline Yes & $9 / 55(16.4)$ & \\
\hline No & $13 / 124(10.5)$ & 0.269 \\
\hline
\end{tabular}

Table 5. Factors independently influencing the occurrence of major morbidity and mortality

\begin{tabular}{lcc}
\hline & Comparison & p \\
\hline $\begin{array}{l}\text { Major morbidity } \\
\quad \text { Perioperative blood transfusion }\end{array}$ & Yes vs. no & 0.034 \\
$\quad$ APACHE II score & $\geq 8$ vs. $<8$ & 0.009 \\
Mortality & & \\
$\quad$ Age & $\leq 65$ vs. $>65$ & 0.002 \\
$\quad$ Perioperative blood transfusion & Yes vs. no & 0.022 \\
\hline
\end{tabular}

are treated more often with single-stage surgery. ${ }^{[12]}$ In our study, resection-anastomosis was frequently carried out in a group of patients with resectable right colon tumors. In 
(a)

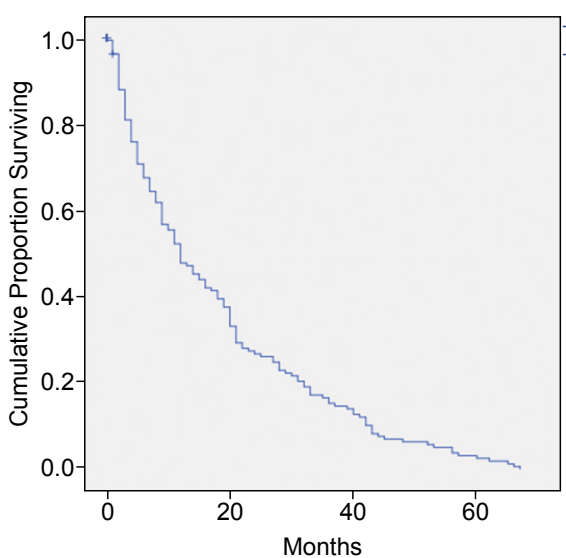

(c)

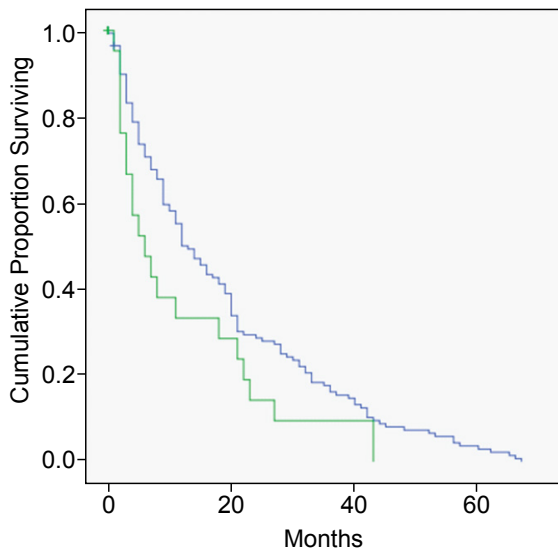

(b)

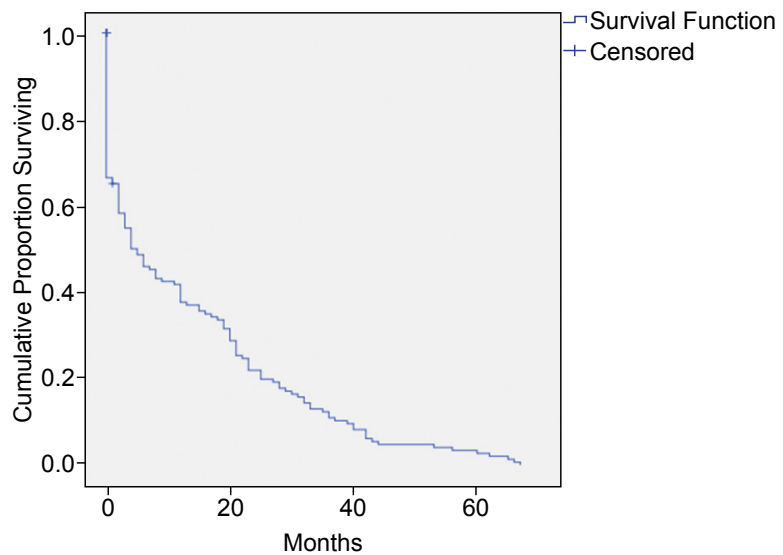

(d)

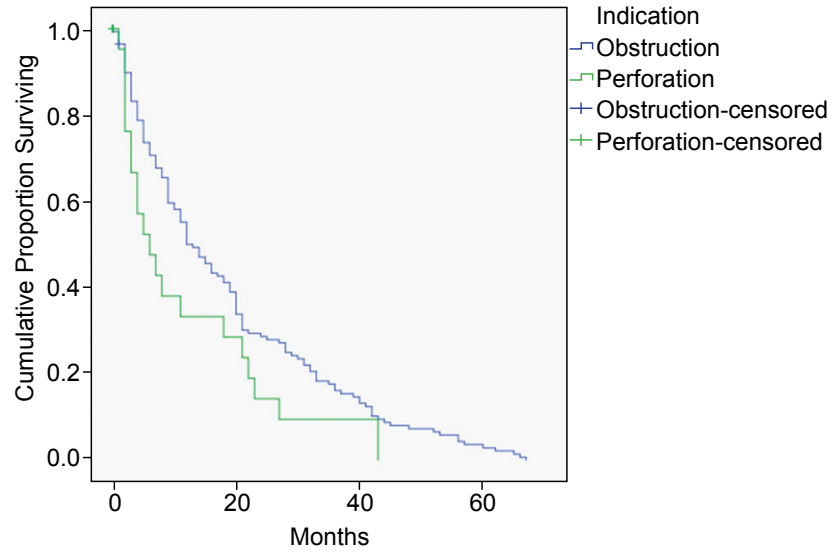

Figure 1. (a) Overall survival. (b) Disease-free survival. (c) Overall survival for obstructive and perforated cases. (d) Disease-free survival for obstructive and perforated cases.

resectable left colon tumors, we used the Hartmann procedure, most often in patients in the obstruction group with resection-anastomosis perforation. Several non-randomized studies have shown the Hartmann's procedure does not have any benefits in mortality. ${ }^{[1,15]}$ Indeed, most of the studies have shown the Hartmann's procedure to be associated with a poorer prognosis, which is most likely related to selection bias, as anastomosis is avoided in high-risk patients. ${ }^{[16]}$

Several studies found that the rates of morbidity and mortality in emergency colorectal surgery were $15 \%$ to $50 \%$ and $6 \%$ to $15 \%$, respectively. ${ }^{[14,17]}$ It is not clear whether the majority of these studies are partial or total obstruction. Thus, different mortality rates are reported. In this study, the mortality rate was similar to previous study results, but we found higher morbidity rates. Comorbidities, electrolyte imbalance, dehydration, inflammatory processes due to surgery on dilated and dirty colonic segments may be attributed to high rates. In these cases, sepsis and multiorgan failure may present.

In general, incidental findings during surgery do not require additional procedures. These findings do not have any corre- lation with the underlying disease. Clinical entities impairing patients' status and iatrogenic causes may require additional procedures. ${ }^{[12]}$ In our study, additional procedures did not bring on any increase in mortality and morbidity.

Postoperative morbidity affects the length of hospital stay, the likelihood of a surgical site infection and mortality rate. One of the most feared major complications of colorectal surgery is an anastomosis leak. Some studies have shown that wound complications are higher after resection and primary anastomosis, especially in patients with left colon carcinoma.

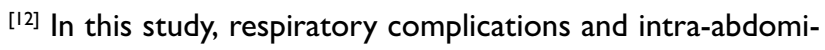
nal sepsis/abscess were more frequent.

The presentation of emergency treatment outcomes due to CRC can be used to predict pre-treatment risks and determine subsequent treatments. Predicted risks for adverse outcomes may be assessed by one or two variant analyzes of the initial diagnostic or surgical type or possible risk factors. ${ }^{[12]}$ We evaluated the possible risk factors for morbidity and mortality by conducting a multivariate analysis with a sufficient number of patient outcomes in this study. 
Some authors have suggested that older age does not cause worsening of prognosis in CRC patients, ${ }^{[10,13]}$ but there are also authors who have shown that this factor is relevant to mortality. ${ }^{[12]}$ We found that patient age is an important prognostic marker in univariate and multivariate analysis and has an independent effect on mortality in this study.

The prognosis of patients who undergo urgent surgery due to intestinal perforation is not clear. Some studies have shown that bowel perforation has a negative effect on patient outcomes. ${ }^{[18]} A$ small number of retrospective studies addressing the differences between obstructive and perforated colon cancers have been published. ${ }^{[12,19]}$ In addition, specific comparisons of for short and long term outcomes between cases of obstruction and perforation are not available in the literature. In most studies, emergency cases are grouped together (obstruction, bleeding, and perforation)..$^{[5]}$ In our study, we could not statistically prove that there was a different effect as a result of obstruction or perforation on major morbidity and mortality.

Surgery for advanced disease has been reported to increase complications and the risk of surgical mortality, ${ }^{[20]}$ and some publications have reported that tumor stage is not a risk factor for mortality and morbidity. ${ }^{[12]}$ Although the majority of patients with major morbidity and mortality in our study were TNM stage III and IV patients, no statistical significance was found.

Some scoring systems are used in the estimation of surgical outcomes, but there are some limitations. The ASA scoring system is the most reliable and useful of these scoring systems.

A higher ASA score generally represents a poorer prognosis for the patient. ${ }^{[2]}$ We could not prove the effects of the ASA score on morbidity and mortality in our study. Recent studies have also shown that APACHE II is one of the most accurate scoring systems for predicting perioperative complications in patients undergoing surgical treatment. ${ }^{[22]}$ In this study, multivariate analysis, although not associated with APACHE II scores of morbidity and mortality in univariate analysis were associated with major morbidity.

In a previous study, blood transfusion in a noncardiac surgical procedure was reported to be associated with hospital mortality and increased risk of septic, wound and thromboembolic complications. ${ }^{[23]}$ Another study indicated that perioperative blood transfusion increased the incidence of bacterial infection after colorectal surgery. ${ }^{[2]}$ In this study, univariate analyses showed that blood transfusion did not differ significantly from morbidity and mortality when compared to those who did not transfuse. However, multivariate analyses found that perioperative blood transfusion was a risk factor for both morbidity and mortality.
In the literature, a long-term survey analysis of patients undergoing CRC related emergency surgery was performed. OS and DFS of the patients who underwent surgery due to CRC obstruction and perforation were worse than patients who underwent elective procedure. ${ }^{[25]}$ Our results revealed no significant difference in OS and DFS between cases of perforation and obstruction.

In conclusion, as reviewed above in light of previous studies, the perioperative morbidity and mortality are still high in patients with CRC who require urgent surgery due to various complications. Given that perioperative blood transfusions are associated with more instances of a major complication or mortality, they should be avoided during surgery, if possible. In addition, the APACHE II score is associated with major complications and advanced age mortality. Thus, the surgeon should treat patients with these criteria more carefully. Considering the data we obtained and discussed in this study, we should note that the effective implementation of CRC-screening policies, which enable early detection and treatment of this disease, could be life-saving. Early diagnosis remains a major factor in the successful treatment of CRC.

\section{Conflict of interest: None declared.}

\section{REFERENCES}

1. Ferlay J, Soerjomataram I, Dikshit R, Eser S, Mathers C, Rebelo M, et al. Cancer incidence and mortality worldwide: sources, methods and major patterns in GLOBOCAN 2012. Int J Cancer 2015;136:E359-86.

2. Bayar B, Yılmaz KB, Akıncı M, Şahin A, Kulaçoğlu H. An evaluation of treatment results of emergency versus elective surgery in colorectal cancer patients. Ulus Cerrahi Derg 2015;32:11-7. [CrossRef]

3. Altobelli E, Lattanzi A, Paduano R, Varassi G, di Orio F. Colorectal cancer prevention in Europe: burden of disease and status of screening programs. Prev Med 2014;62:132-41. [CrossRef]

4. Talebreza A, Yahaghi E, Bolvardi E, Masoumi B, Bahramian M, Darian EK, et al. Investigation of clinicopathological parameters in emergency colorectal cancer surgery: a study of 67 patients. Arch Med Sci 2017;13:1394-8.

5. McArdle CS, Hole DJ. Emergency presentation of colorectal cancer is associated with poor 5-year survival. Br J Surg 2004;91:605-9. [CrossRef]

6. Smothers L, Hynan L, Fleming J, Turnage R, Simmang C, Anthony T. Emergency surgery for colon carcinoma. Dis Colon Rectum 2003;46:2430. [CrossRef]

7. Biondo S, Martí-Ragué J, Kreisler E, Parés D, Martín A, Navarro M, et al. A prospective study of outcomes of emergency and elective surgeries for complicated colonic cancer. Am J Surg 2005;189:377-83. [CrossRef]

8. Owens WD, Felts JA, Spitznagel EL, Jr. ASA physical status classifications: a study of consistency of ratings. Anesthesiology 1978;49:239-43.

9. Knaus WA, Draper EA, Wagner DP, Zimmerman JE. APACHE II: a severity of disease classification system. Crit Care Med 1985;13:818-29.

10. Jeong DS, Kim YH, Kim KJ. Surgical Outcomes and Risk Factors in Patients Who Underwent Emergency Colorectal Surgery. Ann Coloproctol 2017;33:239-44. [CrossRef]

11. McGillicuddy EA, Schuster KM, Davis KA, Longo WE. Factors predicting morbidity and mortality in emergency colorectal procedures in elderly patients. Arch Surg 2009;144:1157-62. [CrossRef] 
12. Alvarez JA, Baldonedo RF, Bear IG, Truán N, Pire G, Alvarez P. Presentation, treatment, and multivariate analysis of risk factors for obstructive and perforative colorectal carcinoma. Am J Surg 2005;190:376-82.

13. Garcia-Valdecasas JC, Llovera JM, deLacy AM, Reverter JC, Grande L, Fuster J, et al. Obstructing colorectal carcinomas. Prospective study. Dis Colon Rectum 1991;34759-62. [CrossRef]

14. Tekkis PP, Kinsman R, Thompson MR, Stamatakis JD; Association of Coloproctology of Great Britain, Ireland. The Association of Coloproctology of Great Britain and Ireland study of large bowel obstruction caused by colorectal cancer. Ann Surg 2004;240:76-81. [CrossRef]

15. Biondo S, Pares D, Frago R, Marti-Rague J, Kreisler E, De Oca J, et al. Large bowel obstruction: predictive factors for postoperative mortality. Dis Colon Rectum. 2004;47:1889-97. [CrossRef]

16. Trompetas V. Emergency management of malignant acute left-sided colonic obstruction. Ann R Coll Surg Engl 2008;90:181-6. [CrossRef]

17. Gürlich R, Maruna P, Kalvach Z, Peskova M, Cermak J, Frasko R. Colon resection in elderly patients: comparison of data of a single surgical department with collective data from the Czech Republic. Arch Gerontol Geriatr 2005;41:183-90. [CrossRef]

18. Biondo S, Kreisler E, Millan M, Fraccalvieri D, Golda T, Marti Rague J, et al. Differences in patient postoperative and long-term outcomes between obstructive and perforated colonic cancer. Am J Surg 2008;195:427-32.
19. Chen HS, Sheen-Chen SM. Obstruction and perforation in colorectal adenocarcinoma: an analysis of prognosis and current trends. Surgery 2000;127:370-6. [CrossRef]

20. Payne JE, Meyer HJ. Independently predictive prognostic variables after resection for colorectal carcinoma. ANZ J Surg 1997;67:849-53. [CrossRef]

21. Oh NH, Kim KJ. Outcomes and Risk Factors Affecting Mortality in Patients Who Underwent Colorectal Emergency Surgery. Ann Coloproctol 2016;32:133-8. [CrossRef]

22. Haynes SR, Lawler PG. An assessment of the consistency of ASA physical status classification allocation. Anaesthesia 1995;50:195-9. [CrossRef]

23. Glance LG, Dick AW, Mukamel DB, Fleming FJ, Zollo RA, Wissler R, et al. Association between intraoperative blood transfusion and mortality and morbidity in patients undergoing noncardiac surgery. Anesthesiology 2011;114:283-92 [CrossRef]

24. Houbiers JG, van de Velde CJ, van de Watering LM, Hermans J, Schreuder S, Bijnen AB, et al. Transfusion of red cells is associated with increased incidence of bacterial infection after colorectal surgery: a prospective study. Transfusion 1997;37:126-34. [CrossRef]

25. Weixler B, Warschkow R, Ramser M, Droeser R, von Holzen U, Oertli D, et al. Urgent surgery after emergency presentation for colorectal cancer has no impact on overall and disease-free survival: a propensity score analysis. BMC Cancer 2016;16:208. [CrossRef]

\section{ORIJINAL ÇALIŞMA - ÖZET}

\section{Obstrükte ve perforasyonlu kolorektal kanser hastalarına güncel tedavi yaklaşımının değerlendirilmesi \\ Dr. Selçuk Kaya, ${ }^{1}$ Dr. Ahmet Seker, ${ }^{1}$ Dr. Önder Altın, ${ }^{1}$ Dr. Yunus Emre Altuntaş, ${ }^{1}$ Dr. Levent Kaptanoğlu, ${ }^{2}$ Dr. Metin Kement, ${ }^{2}$ Dr. Nejdet Bildik, ${ }^{1}$ Dr. Hasan Küçük'}

${ }^{1}$ S.B.Ü Kartal Eğitim ve Araştırma Hastanesi, Genel Cerrahi Kliniği, İstanbul

${ }^{2}$ Bahceşehir Üniversitesi Tıp Fakültesi Genel Cerrahi Anabilim Dalı, VM Medical Park Hastanesi, İstanbul

AMAÇ: Kolorektal kanserin (KRK) tedavisinde tanıda gecikme önemli bir sorun olmaya devam etmektedir. Birçok olgu akut bağırsak obstrüksiyonu ya da perforasyonundan ötürü acil cerrahi müdehaleyi gerektirir. Bu geriye dönük çalışma akut obstrüksiyon ya da peforasyon için acil cerrahi müdehaleye maruz kalan KRK'li hastaların sağkalımı, erken ameliyat sonrası sonuçları, tedavileri ve klinik durumlarını değerlendirmeyi amaçlamıştır. GEREÇ VE YÖNTEM: 2012-2017 yılları arasında toplam 612 hasta KRK nedeniyle ameliyat edildi. Bu hastalar içinde acil müdehale gerektiren I79 hasta yaş, cinsiyet, komorbidite, fizyolojik durum, cerrahi endikasyon, tümör lokalizasyonu, tümör evresi, perioperatif kan transfüzyon oranı, cerrahi müdehale şekli ve hastanede kalma ve ameliyat geriye dönük olarak değerlendirildi.

BULGULAR: Toplamda 152 (\%85) hastada tam obstrüksiyon, 27 hastada (\%15) perforasyon vardı. Majör ameliyat sonrası komplikasyon hastaların neredeyse yarısında gözlendi. Genel mortalite oranı \% I2 (22 hasta) idi. Obstrüksiyon nedeniyle ameliyat edilen hastaların \% I2'sinde (I8 hasta), perforasyon nedeniyle ameliyat edilen hastaların ise \% 15 'inde (4 hasta) mortalite gelişti. Peroperatuvar kan transfüzyonu ve yüksek ASA skoru majör komplikasyonu öngören bağımsız prognostik faktörler olarak tespit edilirken, ileri yaş ve peroperatuvar kan transfüzyonu mortaliteyi öngören bağımsız risk faktörü olarak bulundu.

TARTIŞMA: Başka çalışmalarda da görüldüğü üzere, bizim yazımızda da acil cerrahi girişim gerektiren KRK hastalarında yüksek oranda peroperatuvar morbidite ve mortaliteye rastladık. Tarama programları yardımıyla erken tanı ve tedavi bu hastalıkta yaşam kurtarıcı rol oynamaktadır. Anahtar sözcükler: Kolorektal kanser; obstrüksiyon; perforasyon.

Ulus Travma Acil Cerrahi Derg 2019;25(6):589-596 doi: 10.14744/tites.2019.03828 